IZA DP No. 7432

Bullying at School and Labour Market Outcomes

Nick Drydakis

May 2013 


\title{
Bullying at School and Labour Market Outcomes
}

\author{
Nick Drydakis \\ Anglia Ruskin University, \\ IZA and Scientific Centre for the Study of Discrimination, Athens
}

Discussion Paper No. 7432

May 2013

IZA
P.O. Box 7240
53072 Bonn
Germany

Phone: +49-228-3894-0

Fax: +49-228-3894-180

E-mail: iza@iza.org

Any opinions expressed here are those of the author(s) and not those of IZA. Research published in this series may include views on policy, but the institute itself takes no institutional policy positions. The IZA research network is committed to the IZA Guiding Principles of Research Integrity.

The Institute for the Study of Labor (IZA) in Bonn is a local and virtual international research center and a place of communication between science, politics and business. IZA is an independent nonprofit organization supported by Deutsche Post Foundation. The center is associated with the University of Bonn and offers a stimulating research environment through its international network, workshops and conferences, data service, project support, research visits and doctoral program. IZA engages in (i) original and internationally competitive research in all fields of labor economics, (ii) development of policy concepts, and (iii) dissemination of research results and concepts to the interested public.

IZA Discussion Papers often represent preliminary work and are circulated to encourage discussion. Citation of such a paper should account for its provisional character. A revised version may be available directly from the author. 


\section{ABSTRACT}

\section{Bullying at School and Labour Market Outcomes}

This study examines the long-term correlates of bullying in school with aspects of functioning in adult employment outcomes. Bullying is considered and evaluated as a proxy for unmeasured productivity, and a framework is provided that outlines why bullying might affect employment outcomes through differences in skills and traits. Using Bivariate and Heckit models we employ a variety of specifications and find several interesting patterns. The regression outcomes suggest that labour force participation, employment rate and hourly wages are negatively affected by bullying. In addition, men, homosexuals, immigrants, unmarried people, those having higher negative mental health symptoms, and those having lower human capital are more negatively affected by bullying in terms of labour force participation, employment probability, and hourly wages. Moreover, Oaxaca-Blinder decompositions suggest that labour force participation gaps, employment gaps and hourly wage gaps between minority and majority groups, especially for gay men and the disabled, can be explained by bullying incidents. It seems likely that having been a victim of bullying also has economic implications later in life due to withdrawal from the labour market and lower wages.

JEL Classification: E24, J21, J24

Keywords: bullying, personality traits and processes, human capital, labour force, employment, wages

Corresponding author:

Nick Drydakis

Lord Ashcroft International Business School

Anglia Ruskin University

East Road

Cambridge, CB1 1PT

United Kingdom

E-mail: nick.drydakis@anglia.ac.uk 


\section{Introduction}

In the last decades, bullying has appeared to be increasingly worsening, causing problems for bullied individuals, their families and their educational environments (Giovazolias et al., 2010). How bullying experiences are defined and measured varies greatly in the literature (Hamburger et al., 2011). Following Olweus's (1993) pioneering work, bullying is recognised as aggressive behavior characterised by repetition and an inability on behalf of the victim to defend him- or herself. Boys and girls are vulnerable to being bullied verbally (e.g., name calling), physically (e.g., hitting), and socially (e.g., spreading rumours, social rejection, extortion, and isolation) (Olweus, 1993; Rigby 1997; Smith and Brain, 2000; Rigby 2003). Despite variation across studies, the victimisation range concerning bullying varies from 5\% to approximately $70 \%$ (Olweus, 1993; Whitney and Smith, 1993; Fonzi et al., 1999; Smith et al., 1999; O’Moore, 2000; Pellegrini and Long, 2002; Pereira et al., 2004; Nansel et al., 2004; Sapouna, 2008; Craig et al., 2009), and bullying has widespread consequences. Studies suggest that bullied students face depression, stress, lower social and global self-esteem and anxiety (Craig 1998; Hawker and Boulton, 2000; Rigby, 2003; Klomek et al., 2008), as well as psychosomatic disorders, emotional problems, and suicidal ideation (Kaltiala-Heino et al., 1999; Woods et al., 2009). Studies also suggest that bullied students have lower academic performance, higher academic difficulties, higher rates of school absences, and higher rates of school loneliness than their non-bullied peers (Holt et al., 2007; Brown and Taylor, 2008; Nakamoto and Schwartz, 2009; Juvonen et al., 2011).

This study examines the long-term correlates of bullying in school with aspects of functioning in adult employment outcomes using the Retrospective Bullying Questionnaire (Rivers 2001; Schafer et al., 2004; Varhama and Björkqvist, 2005; 
Hamburger et al., 2011) in the year 2008 by utilizing the Greek Behavioural Study (GBS) data set. Current studies provide evidence for the association of victimisation with later life functions using retrospective interviews with adults who have experienced bullying. Chapell et al. (2006) and Chapel et al. (2008) report that bullying at school is related to low self-esteem in adult life. Smith (1991), Hugh-Jones and Smith (1999), Rivers (2001) and Smith et al. (2003) report that bullying is related to low confidence around others and lower-quality social relationships in adult life. In addition, Schafer et al. (2004), Jantzer et al. (2006), Newman (2005), Ledley et al. (2006), Dempsey and Storch (2008), and Orth (2009) suggest that the experience of being bullied in school corresponds to difficulties in forming trusting relationships as an adult, as well as greater risk of depression and post-traumatic stress. Espelage and Swearer (2003), Schafer et al. (2004) and Smokwoski and Holland (2005) find that being bullied leads to an update of social expectations likely to produce an insecure internal working model of self-esteem, which then generates adverse social effects in adult life. Moreover, Allison et al. (2009) show that adults who had been bullied as children reported poorer mental and physical health compared to those who had not been bullied. The health problems of bullied individuals often stood in the way of both work and leisure activities. These individuals were more likely to report body aches and pains and to complain of low energy levels and fatigue. Studies do establish the degree of reliability and validity of retrospective research (Brewin, 1993; Mauk and Rodgers, 1994; Rivers 2001; Hamburger et al., 2011). Indeed, depression and flashbacks are most readily associated with post-traumatic stress coming from negative life events such as bullying (Brewin, 1993; Rigby, 2003; Mauk and Rodgers, 1994; Rivers 2001). 
In the current study, we hypothesise that a pattern of victimisation experiences in school would negatively affect adult employment outcomes. We suggest that schoolage bullying may be thought of as part of an individual's set of productive traits. Because bullying is linked to lower academic achievement and higher negative mental health symptoms later in life, it seems likely that having been a victim of bullying also has economic implications later in life due to withdrawal from the labour market and lower wages. The current study aims to answer the following research questions: (1) Are individuals' employment outcomes (e.g., labour force participation rates, employment rates and hourly wages) negatively affected by bullying? (2) Are higher levels of victimisation associated with lower employment outputs? (3) Which demographic groups are more negatively affected by bullying in terms of employment outcomes (e.g., men/women, natives/immigrants, gay men/heterosexual men, etc.)?

Does bullying play a critical role in employment outcome gaps between various demographic groups (e.g., men/women, natives/immigrants, lesbians/ heterosexual women etc.)?

Apart from the novelty of the research questions, the current study advances the literature in many ways. As discussed in Section 2, the major advantage of this study concerns the comprehensiveness of the independent variable: bullying. In the current paper, bullying is considered to be a proxy for unmeasured productivity. An updated literature review that links bullying to academic skills and mental conditions will be the basis for this study's theoretical framework. In Section 3, by describing the dataset, analysing the variables employed in this study and, presenting the descriptive statistics, we discuss many critical insights. Finally, in Section 4, using multivariate 
specifications, various interaction effects, and decompositions, we evaluated several interesting patterns that led us to the study's conclusions.

\section{Theoretical framework}

We adopt a simple framework, which is outlined in the majority of economic studies, to explain how bullying may affect employment outcomes through differences in skills and mental health. Most of the economic literature on the determination of labour market outcomes has concentrated on traditional human capital variables, such as education and skills (Mincer, 1958; Becker, 1975; Lemieux, 2006). Human capital is one of the most important factors affecting employment and labour productivity. Education and skill acquisition increase human capital, employment and wages. Therefore, there is a close relationship between human capital, wages and productivity. An individual's overall compensation depends on the type and amount of skills possessed and the return that each subcomponent of the skill vector earns in a given occupation. If victims of bullying invest less in human capital, one could expect that their employment outcomes will be lower than that of those who did not face childhood victimisation. Indeed, a meta-analysis of 33 scholarly studies shows that bullied students achieve lower academic performance and grades (Nakamoto and Schwartz, 2009). Importantly, studies show that employers believe grading scales are useful predictors of cognitive ability, affecting productivity, effectiveness and responsibility, and make hiring and wage decisions based on grading scales (Roth et al, 1996; Miller, 1998; Turban and Cable, 2003). Indeed, Waddell (2006) and Brown and Taylor (2008) estimate that bullying has an adverse effect on human capital accumulation, which negatively influences employment and wages. Similarly, Le et al. (2005) show that 
bullying is linked to school dropouts and poor labour market outcomes. Boswoth (1994), Grogger (1997), Nishina et al. (2005), Smokowski and Kopasz (2005), Schwartz et al., (2005), Waddell (2006), Amermueller (2007) and Juvonen et al. (2011) suggest that a student who is bullied by peers becomes worried about verbal and physical harassment. This student stops participating in class and has trouble concentrating on academic tasks because of compromised self-regulation, eventually suffering from academic difficulties that influence human capital and efficiency.

Moreover, the retrospective studies reviewed in this paper have suggested an association between being bullied at school and long-term psychic adjustment (Chapel et al., 2008; Dempsey and Storch, 2008; Allison, 2009; Orth, 2009). As previously discussed, adults with a history of being bullied are likely to develop depression, anxiety, personality disorder, and loneliness. Economists increasingly view mental health as having important consequences for the economic decisions made by individuals and the outcomes they achieve. Studies suggest that adverse mental health symptoms (e.g., depression, anxiety, and neuroticism) and personality traits (e.g., low self-esteem, low confidence and ability to trust) negatively influence employment status and earnings, suggesting that adverse mental health symptoms and personality traits should be considered unobserved productivity traits (Farmer, 1995; Fergusson and Horwood, 1998; Gregg and Machin, 2000; Dooley et al. 2000; Savoca and Rosenheck, 2000; Waddell, 2006; Mueller and Plug, 2006; Heineck and Anger, 2010). Thus, because bullying is negatively associated with mental capacities and personality, bullying may be regarded as an unobserved productivity trait or pattern that may influence returns to labour market activity (see, Varhama and Björkqvist, 2005; Vreeman and Carroll, 2007). Goodman et al. (2011) find that mental health problems in 
childhood are shown to have a much greater impact on long-run economic outcomes than physical health problems. According to this research, psychological problems occurring in childhood are associated with reduced family incomes and reduced labour force participation throughout adulthood.

Thus, in the current study, we suggest that labour force participation, unemployment rates, and hourly wages might be negatively affected by bullying status. The available studies suggest that such a pattern may be due to victims' lower academic achievements, higher negative mental health symptoms and the associated productivity implications. Furthermore, we should mention that differences in employment structures and wages may also be affected by labour market discrimination against victimised individuals, either due to distastes for bullied people (Becker, 1993) or employer uncertainty regarding the productivity and work commitment of bullied individuals (Arrow, 1998). Indeed, the retrospective studies discussed in the introduction suggest that victimised individuals exhibit characteristics of vulnerability, such as sub-assertive behaviors, that make them attractive targets for unfavorable evaluations (Espelage and Swearer, 2003; Schafer et al., 2004; Chapell et al., 2006; Chapel et al., 2008; Dempsey and Storch, 2008; Orth, 2009). One may even conceive of discrimination against victims that starts before they enter the labour market. It has been hypothesised that children with adverse mental health problems, such as depression or anxiety, are more vulnerable to being bullied and discriminated against by other children (Schwartz et al., 1993; Schwartz et al., 2005). These individuals may be discouraged from entering specific fields of work or participating in the labour force. The same holds whenever individuals may have different work-related preferences. If these differences are related to bullying, bullying may indirectly affect employment and wages through occupational 
processes. Note, however, that, although discrimination and work preferences may play a crucial determinant role, it is difficult to empirically separate differences in employment that are due to discrimination and preferences from differences in educational skills and mental health symptoms.

What we should discuss is the process that leads to long-term negative patterns of bullying among former victims that may affect their human capital, labour participation, workplace relations and wages. Applying a resilience framework informed by positive psychology and cognitive theory, bullying is considered a stressor if is perceived by the victim as an on-going threat to physical safety, emotional wellbeing and self-esteem (Albee, 1988; Roth et al., 2002; Meyers and Meyers, 2003; Newman et al., 2005). The tendency to internalise bullying victimisation may lead to a life-belief that being the target of bullying indicates that the victim is flawed and unable to affect the outcomes of other situations. If this tendency toward negative internalisation persists, these people may be at greater risk for negative mental health symptoms that affect their future choices, such as education, labour participation, effectiveness, productivity, and employment relations life (Meyers and Meyers, 2003; Newman et al., 2005). In addition, people who have experienced additional stressors are at greater risk for decreased opportunities for positive adjustments. Moreover, people with a predisposition for depression might be more likely to exhibit problems associated long-term effects of bullying, such as depression, anxiety, loneliness and problems in relationships, which could negatively affect their workplace record life (Meyers and Meyers, 2003; Newman et al, 2005). However, persons who make more positive appraisals of events are more likely to experience positive effects in later life (Meyers and Meyers, 2003; Newman et al, 2005). 


\section{Data and descriptive statistics}

\subsection{Variables Definition}

The data were gathered from January 2008 through December 2008 in the Greek Behavioural Study (GBS), which was conducted by the University of Piraeus, the University of Central Greece, and the Panteion University of Social and Political Sciences. The 2008 GBS is one component of the Multi-country Study of the Scientific Centre for the Study of Discrimination (SCSD), which has collected information on Greek citizens. The 2008 GBS consisted of random telephone-based surveys. Individuals in each household were randomly selected to provide information on a variety of demographic characteristics. Interviews were restricted to individuals aged 18 to 65 years (the upper limit corresponding to the official retirement age in Greece).

Respondents were asked to answer three separate questions: whether they were employed, whether they were unemployed (people without work and actively seeking work), and whether they were inactive (people without job and not looking for a job). Wages were measured as a continuous variable. The GBS constructed an hourly wage measure by dividing the last month's wages by self-reported working hours per month. Surveyors asked, "What is your best estimate of your wage last month before taxes and other deductions?" For convenience, variable definitions are summarised in the Appendix.

There are many methods for measuring levels of bullying, but the most common is the Likert (1932) scale. The GBS follows the format of a typical ordered-level Likert (1932) item. We follow the questionnaire used by Rivers (2001), Schafer et al. (2004) and Varhama and Björkqvist, (2005) which covers the experience of victimisation at school age (see also, Hamburger et al., 2011). Surveyors asked, "The following two 
questions are about bullying: (1) Please think back to your school days, up to eighteen years old. You may have got bullied by others in some way. Choose which best describes your own experience at school: Never bullied, rarely bullied, sometimes bullied, frequently bullied, constantly bullied. (2) In addition, if you have been bullied, how serious did you consider these bullying attacks to be? Not at all serious, only a bit serious, quite serious, extremely serious". Several studies suggest that frequency and intensity of bullying are the primary contributing factors to the development of longterm social problems during adulthoods (Newman et al., 2005; Jantzer et al., 2006; Hamburger et al., 2011). Thus, a comprehensive study may consider their combined effects (see for instance, Newman et al., 2005; Jantzer et al., 2006; Hamburger et al., 2011). The Bullying Index used in this study measured the combined and ordered effect of each individual's experience during school age (i.e. frequency $x$ intensity) which generates seventeen outcomes that ultimately capture a large range of alternative options (Newman et al., 2005; Jantzer et al., 2006; Hamburger et al., 2011). Table 1 presents the potential combinations.

\section{[Table 1]}

Numerous factors besides school bullying may influence employment outcomes. Some of these factors pertain to individual productivity. The variable age measures the individual's age in years. To account for the possibility that past victimisation may differ across gender, a dummy variable for gender is included. The variable married measures marital status. The variable children measures how many children the respondent has. The GBS also included a direct question about sexual orientation. To investigate sexual orientation, employees were asked the following: "The next question 
is about sexual orientation: Do you consider yourself to be: (1) Heterosexual? (2) Homosexual?"

In addition, the variable immigrant measured whether the respondent was an immigrant (i.e., non-Greek). To capture possible effects of disability and disease, the variable health impairments measured whether the respondent was limited by poor health. To be comparable to previous research, we defined disability status using the self-reported response to a question concerning conditions that limited the individual's ability to work (see, Baldwin and Johnson, 2000). Similarly, the variable mental health symptoms measures adverse mental health symptoms experienced in the last week. The scale, which was defined by the Centre for Epidemiology Studies (CES-D, 20 items), measures the existence of adverse mental health symptoms. Studies have confirmed the validity and reliability of this score as a screening instrument for the evaluation of major depression, subjective well-being, and disposition (Radloff, 1977; Irwin et al., 1999; Stanbury et al., 2006; Shenkman and Shmotkin, 2011).

Moreover, to deal with unobserved heterogeneity between individuals we use the Big Five Personality Inventory (Digman, 1990; McCrae and John, 1992). The most widely cited component of individual's heterogeneity is individual's personality. Many studies have made the explicit assumption that the unobservable individual heterogeneity is mainly personality traits (Ferrer-i-Carbonell and Frijters, 2004; Booth and van Ours, 2008). Big Five Personality Inventory index suggests that there are five dimensions of personality: openness to experiences, conscientiousness, extroversion, agreeableness and emotional stability. Studies suggest that this index help to explain why even after controlling for many factors, which includes the improved cognitive abilities that come through education, there are still large employment and education 
gap (Boyce, 2010). Indeed, the Big Five Personality Inventory controls various critical heterogeneities such as social recognition, commitment, popularity, energy level, selfesteem, physical attractiveness based on 40 behaviour criteria (Paunonen and Ashton, 2001).

The variable university measured whether the respondent had a university or technical-school diploma. The variable computer measured whether the respondent had computer skills. The variable English measured whether the respondent had knowledge of English. The variable experience measured the individual's years of actual work experience. Finally, two dummy variables for occupational categories were included. The variable white measured whether the individual's occupation was considered whitecollar. The variable public measured whether the respondent was employed in the public sector.

\subsection{Descriptive statistics}

The sample consists of 7,500 respondents, however 1,183 respondents with missing information were dropped from the analyses (i.e. 15.7\%). Table 2 shows the descriptive statistics, and this section offers a brief discussion. We present the descriptive statistics for those cases for which we have complete information about the variables under consideration: bullying. What is of interest, however, is that the mean and standard deviation are the same for (i) individuals who did not answer the bullying questions (342 cases, i.e., 5.1\%) and (ii) individuals who answered the bullying questions $(6,317$ cases, i.e., $94.8 \%)$. This pattern suggests that the response rate might not be affected by an individual's employment status, age, sexual orientation, ethnicity, disability and mental health status, university degrees, work experience, and job sector. 
Mean tests were employed, and none of the attempts concurred with the null hypothesis of a significant difference between groups (i) and (ii). Tables are available on request. The underlying explanation may be that individuals might have felt bothered by the bullying questions and declined to provide an answer, regardless of their demographic characteristics. It is not possible, however, to exclude the possibility of unobservable individual characteristics affecting the probability of respondents (not) answering.

[Table 2]

In Table 1, we present the proportion estimations of the key variables, frequency of bulling (FB), intensity of bulling (IB), and the bullying index (B). The raw numbers suggest that $76.5 \%$ of the respondents have never been bullied, $9.6 \%$ have rarely been bullied, $5.2 \%$ have sometimes been bullied, $7.9 \%$ have frequently been bullied, and $0.5 \%$ have constantly been bullied. In addition, of those who have been bullied, $31.0 \%$ suggest that the bulling experience was not at all serious, $20.3 \%$ suggest that it was only a bit serious, $41.1 \%$ suggest that it was quite serious, and $7.4 \%$ suggest that it was extremely serious.

The bullying index shows a great variability in responses, which demonstrates why the measure is scientifically correct. For instance, $6.7 \%$ of the respondents suggest that rarely have they been bullied but it was not at all serious, $2.4 \%$ suggest that sometimes they have been bullied and it was quite serious, $6.3 \%$ suggest that frequently they have been bullied and it was quite serious, and $0.2 \%$ suggest that constantly have been bullied and it was extremely serious. The reliability of the scales is considered to be satisfactory (Frequency of bullying Cronbach's $\alpha=0.84$, Intensity of bullying Cronbach's $\alpha=0.81$, Bullying index Cronbach's $\alpha=0.84$ ). 
Note that given the nature of retrospective bullying, there is a risk of underreporting as a result of factors such as a desire to forget unpleasant events or a sense of shame (Schafer et al., 2004). It is difficult to provide any measure of the extent of under-reporting, but we can at least assess whether the responses within Greek Behavioural Study align with other sources from Greece. In the Greek Behavioural Study, $23.5 \%$ of individuals claim to have been victims of bullying at least rarely (that is, $\mathrm{FB}>0$ ). Giovazolias et al. (2010) estimate that $22.8 \%$ of students are victims of bullying. Sapouna (2008) suggests that $8.2 \%$ of students are victims of bullying, and Pateraki and Houndoumani (2001) find that $14.7 \%$ of students are victims of bullying. These differences may be due to methodological issues used in the collection of data and fluctuations in the emergence of the phenomenon based on the socio-economic situations of the sample and the school environment, which might vary between samples (Giovazolias et al., 2010).

The average age, as shown in Table 2, is 34.6 years, and $47.4 \%$ of the subjects are men. The results indicate that $58.3 \%$ are married, $15.4 \%$ are immigrants, and $7.7 \%$ are disabled. Regarding education levels, $47.9 \%$ have a university or technical school degree. The labour force (employed and unemployed people) consists of $78.1 \%$ employed people and $21.0 \%$ unemployed people. The non-participants are on the order of $7.0 \%$. In addition, $39.8 \%$ are white collar employees, and $52.7 \%$ are public employees. Individuals have an average 12.5 years of work experience, and the hourly wage rate is 7.9 Euros $^{1}$.

\footnotetext{
${ }^{1}$ Based on the General Confederation of Greek Workers for the period 2007-8, the minimum legal hourly wage for unmarried workers without experience was $4.31 €$. In
} 
Notably, given the absence of census data, testing whether this sample is truly representative is virtually impossible. However, this issue has been addressed by comparing the GBS's descriptive statistics with those of the most recent Greek Household Budget Survey from 2005. A comparison of the two data sets reveals similar average ages for the respondents, as well as similarity across gender composition, proportion of immigrants, wage rates, and participation in occupations and sectors. This comparison suggests that the GBS survey is, to a large extent, representative of individuals in Greece.

After having presented the aggregate measures, we can acquire valuable information by examining differences in the bullying indicators across employed, unemployed and non-participating individuals. In Table 3, we have separated the categories. On average, the outcomes suggest that lower bullying experiences are observed for employed individuals than for unemployed and non-participating individuals. These patterns are in line with the studies discussed in the literature review section (see for instance, Le et al. 2005, and Brown and Taylor, 2008).

\section{[Table 3]}

We also investigate the inter-correlation matrix, which is used to determine whether bullying affects each of the variables used in this study. In Table 4, we present a sub-correlation matrix (28x3). The whole inter-correlation matrix $(28 \times 28)$ is available on request. The outcomes suggest that there is a positive and statistically significant correlation between bullying and males. In addition, there is a positive and statistically significant correlation between bullying and homosexuality and between bullying and

each group, every three additional years of working experience yielded approximately a $0.35 €$ increase in the minimum wage. 
being an immigrant. There is also a negative correlation between bullying and age. Additionally, there is a negative correlation between bullying and marriage and between bullying and an individual's number of children. A positive and statistically significant correlation is identified between bulling and disability and between bullying and negative mental health symptoms. In addition, there is a negative and statistically significant correlation between bullying and extraversion traits (i.e. cheerfulness, excitement-seeking). Importantly, there is a negative and statistically significant correlation between bullying and human capital (higher degrees, P/C and English skills). In addition, there is a negative and statistically significant correlation between bullying and employment levels and between bullying and participation in the labour force. As a result, bullying is also negatively and statistically significantly correlated with actual work experiences. Moreover, bullying seems not to affect individuals' choices of job sectors and occupations. However, there is a negative and statistically significant correlation between bullying and hourly wages.

\section{[Table 4]}

An endless analysis of each correlation's coefficient rank could take place at this stage. On average, however, all these patterns are comparable and in line with the outcomes discussed in the literature review (see also, Farmer, 1995; Fergusson and Horwood, 1998; Gregg and Machin, 2000; Espelage and Swearer, 2003; 2005; Smokwoski and Holland, 2005; Waddell, 2006; Amermueller, 2007; Brown and Taylor, 2008; Dempsey and Storch, 2008; Giovazolias et al., 2010; Goodman et al., 2011). 


\section{Estimations and Discussion}

\subsection{Estimation strategy}

In this study, we have hypothesised that bullying may affect labour force participation $(L)$, employment outcomes $(E)$, and wage rates $(\ln W)$. Importantly, employment outcomes are observed only for those who are in the labour force. Similarly, wages are observed only for those who are employed. Concerns about sample selection bias might be raised (see, Heckman, 1979). It is important to consider for such unobserved heterogeneity given that bullying is likely not to affect a random subset of the population as a whole. Indeed, if bullied people's unemployment is substantial and leads them to exit the labour force, the estimate of employment would be a biased estimation. In addition, using data only on employees in the wage estimation might be inappropriate because the wages of those who choose to work may not necessarily give valid estimates of potential wages of those who did not work. In the current study, an estimated procedure proposed by Heckman (1979) is applied which translates sample selection into a problem of an omitted variable. Methodologically, by estimating the labour force participation equation $(L)$ we construct an Inverse Mills Ratio (IMR) term that is served as a statistical correction for the employment equation $(E)$, and wage equation $(\ln W)$. The above relationships can be expressed as following.

A Bivariate Probit model with sample selection (Wooldridge, 2006) is used in order to estimate the probability that one is employed $(\mathrm{E})$ :
Labour force participation:

$$
L_{i}=\beta_{1} B_{i}+\delta_{1} Z_{i}+\gamma_{1} K_{\iota}+e_{i 1}
$$$$
\text { equation (1) }
$$
Employment:

$$
E_{i}=\beta_{2} B_{i}+\delta_{2} Z_{i}+v \widehat{\lambda_{l}}+e_{i 2}
$$
equation (2) 
where, $L$ equals to 1 if individual belongs to the labour force, and 0 if individual is inactive; $E$ equals to 1 if the individual is employed, and 0 if the individual is unemployed; $B$ is the bullying index. In vector $Z$, we control for a standard set of variables, including age, gender, marital status, number of children, ethnicity, sexual orientation, disability status, mental health, personality traits, higher education, actual working experience, computer skills and knowledge of English. In vector K, we control for a standard set of variables that help the labour force participation model's identification, including: non labour income, and the highest educational attainment of the respondent's mother and father. Studies make assumptions that non labour income, and parents' education are associated to an individual's labour force participation probability $^{2}$ (Heineck and Anger, 2010). The term $\hat{\lambda}_{l}$ is the Inverse Mills Ratio for each observation in the sample of individuals. In addition, $\beta, \delta, \gamma$ and $v$ are the parameters to be estimated, and $e_{1}$, and $e_{2}$, are the error terms. The key variables of interest are the parameters indicating bullying experiences. Statistically significant negative coefficients would imply lower labour force participation (equation 1), and lower employment rates (equation 2).

In the same vein, the model of wages $(W)$ is estimated through a Heckit model (Wooldridge, 2006):

\footnotetext{
${ }^{2}$ However, it should be kept in mind that the effects we try to measure in our sample cannot be fully generalized to the total population without reservation. Whilst, it might be argued that the excluded variables are correlated with unobserved characteristics of the individuals.
} 
Labour force participation: $\quad L_{i}=\beta_{1} B_{i}+\delta_{1} Z_{i}+\gamma_{1} K_{\iota}+e_{i 1}$

equation (1)

Hourly wages:

$$
\ln W_{i}=\beta_{3} B_{i}+\delta_{3} Z_{i}+v \widehat{\lambda_{l}}+e_{i 3}
$$

equation (3)

where, $W$ denotes the natural logarithm of hourly wages. The key parameter of interest is $\beta_{3}$. A statistically significant negative coefficient would imply lower hourly wages against bullied people.

We should highlight that this study is not affected by endogeneity between employment outcomes and past victimisation. Although bullying may affect employment outcomes, we cannot suggest that participation in the labour force, (un)employment rates and wages may affect past school-age victimisation. Thus, the current framework is unaffected by endogeneity that biases various socio-economic phenomena.

Importantly, note that the findings to be presented provide evidence of correlations rather than direct evidence of causation. We will present outcomes that establish correlations between bullying and employment outcomes. We cannot firmly evaluate, for instance, whether lower wages are the result of past victimisation. It is an open question whether various social experiences after leaving the school environment can counteract earlier bullying experiences. Because these relationships are correlated, no causal direction is established. In other words, there may exist a "third factor" causing both bullying and negative performance in the labour market.

In addition, we should also note that although we use a mental health symptoms index, and personality trait indexes to capture potential effects, this subject is not within the study's scope. It is difficult to evaluate why mental health symptoms and personality traits exist and whether these symptoms/personality traits are the result of past 
victimisation. The same holds for the rest of the independent variables used in this study (e.g., disability, marital status, higher education, employment sector etc).

In addition, the accuracy level of retrospective recall of past victimisation presents a potential source of bias. This bias is more likely to under-report bullying than to over-report it. However, it is difficult to provide a hypothesis on whether the possible under-reporting would create an upward or downward bias in the current employment estimations. It could be that people who are now doing well in their social life and employment are better able to cope with past victimisation and are more willing to report having been bullied. If this is the case, then the study's empirical results understate the true level of disadvantage. On the other hand, if the same people want to forget past victimisation in the context of later life success, then the current estimations would overstate the disadvantage. In this paper, as in most other studies, we take the numbers at face value and study the implied patterns in Greek society.

\subsection{Outcomes' analysis}

In Table 5, we present equation's 1 regression outcomes of the determinant factors concerning whether one participates in the labour force (marginal effects). In Panel II, we present the equation's 2 estimations of the factors that affect one's employment probability (marginal effects). In Panel III, we present equation's 3 hourly wage (ln) regression.

\section{[Table 5]}

The regression outcomes suggest that labour force participation, employment rate and hourly wages are negatively affected by bullying (bullying index), at least at the 5\% significance level. To be precise, the regression outcomes suggest that a one- 
standard deviation increase of the bullying variable is associated with a $4.1 \%$ decrease in the participation rate, $3.3 \%$ decrease in the employment rate, and $2.1 \%$ decrease in hourly wages ${ }^{3}$. These patterns are in line with those of Varhama and Björkqvist (2005), Waddell (2006), Amermueller (2007), Brown and Taylor (2008), and Goodman et al. (2011). With respect to other variables of interest, results in the regressions are as expected. We briefly discuss the statistically significant outcomes. Men are more likely to participate in the labour force, to be employed and to receive higher hourly wages. Age has a positive effect on wages and a negative effect on employment status. That is, young people receive lower wages and face higher levels of unemployment. The higher education and marriage variables have a positive effect on participation in the labour force and wages. Actual work experience has a positive impact on all specifications. P/C skills positively affect the probability that one is employed. Disability status, adverse mental health symptoms, foreign ethnicity, and homosexuality negatively affect employment and wages. Concerning the occupation covariates, those in white-collar jobs and those in public jobs receive higher wages. The ranking of the parameter coefficients is also interesting. Employing Wald tests, bullying has the lowest negative impact compared to the other negative effects, such as disability, ethnicity, and sexual orientation. But bullying is still a statistically significant variable. The importance of the bullying variable can also be assessed by the fact that, if we regress the three specifications without the bullying variable, we receive lower $\mathrm{R}^{2}$ than if we consider the

\footnotetext{
${ }^{3}$ Note that if, instead of the bullying index (B), we use the frequency of bullying variable (FB), the intensity of bullying variable (IB), or both, we estimate comparable patterns. Tables are available on request.
} 
bullying variable. In other words, the outcomes become more precise when we consider the bullying variable.

In Table 6, we present additional information regarding the impact of bullying. We employ nine dummy variables, as discussed in Tables 1, to capture the impact on employment outcomes of "Never bullied", "Rarely bullied but not at all serious", etc ${ }^{4}$. In general, for all specifications, there is a negative relationship between bullying and employment returns. Individuals without a history of being bullied have a higher and statistically significant probability of participating in the labour force, being employed, and receiving higher wages. On the other hand, individuals who were constantly bullied and those who experienced a quite to extremely serious intensity of bullying face the highest and statistically significant negative effects in terms of lower participation in the labour force, lower employment rates, and lower hourly wages. We conclude that a higher level of bullying, in terms of frequently and intensity, is associated with lower employment outputs.

\section{[Table 6]}

In Table 7, we perform additional regressions using the bullying index's interaction effects (Braumoeller, 2004; Brambor et al. 2006). We present the statistically significant outcomes. Men are more negatively affected by bullying than women in terms of labour force participation, employment probability and wages. The studies reviewed, as well as the sub-correlation matrix in Table 4, suggest that males are more vulnerable to victimisation and are affected more by bullying than women (see also, Menesini et al., 2003; Andreou and Mettalidou, 2004).

\footnotetext{
${ }^{4}$ For precise outcomes we use dummy variables for those categories having at least 15observations (see, Table 1).
} 
[Table 7]

Moreover, homosexuals and immigrants are also more negatively affected by bullying in terms of labour force participation, employment probability and wages than heterosexuals and natives, respectively. Indeed, studies suggest that minorities face high levels of bullying, which affects many functions of their future lives (see also, Schwartz et al., 2003). In addition, the economic returns to bullying are lower for unmarried people. That is, unmarried people are more affected by bullying and face lower levels of labour force participation, employment probability and higher wages (see also, Schwartz et al., 2003). Individuals with higher negative mental health symptoms are more negatively affected by bullying in all three employment specifications than those having lower negative mental health symptoms (see also, Schwartz et al., 2003). Scholarly studies suggest that there is a strong relation between the act of bullying and mental health symptoms, which in turns affects various economic aspects of victims' lives (Allison et al., 2009). Individuals who have more human capital (i.e., individuals who hold university or technical school degrees) and those with more years of actual work experience are less negatively affected by bullying in terms of labour force participation, employment probability and wages ${ }^{5}$. These retrospective outcomes suggest a potentially important transmission mechanism between bullying, human capital and traits, and labour market outcomes (see, Gregg and Machin, 2000). Similarly, studies highlight the relationship between bullying, academic achievement

\footnotetext{
${ }^{5}$ If, instead of the bullying index (B), we use the frequency of bullying variable (FB), the intensity of bullying variable (IB), or both, we estimate comparable patterns. Tables are available on request.
} 
and the associated long-term economic consequences (see, Varhama and Björkqvist, 2005; Waddell, 2006, Le et al, 2005; Brown and Taylor, 2008).

Finally, we are interested in examining the role played by the bullying index with respect to labour force participation gaps, employment rate gaps and wage gaps between various demographic groups. In Table 8, we present the results of five OaxacaBlinder wage decompositions - specifically, we consider men-women, nativesimmigrants, heterosexual men-gay men, heterosexual women-lesbians and healthyhealth impaired people ${ }^{6}$. In Panel I, we present the raw differences. In Panel II, we

${ }^{6}$ An often-used methodology for studying labor market outcomes by groups is to decompose mean differences in unemployment levels or wages based on regression models in a counterfactual manner. The procedure is known in the literature as the Blinder-Oaxaca decomposition (Blinder 1973; Oaxaca 1973; Dolton and Kidd, 1994) and divides the differential between two groups into a part that is "explained" by group differences in various socio-economic characteristics and a residual part that cannot be accounted for by such differences. This "unexplained" part is often used as a measure for discrimination, but it also subsumes the effects of group differences in unobserved predictors. For instance, the difference in labour force participation between men (M) and women (W) can be decomposed as follows: $\bar{P}_{M}-\bar{P}_{W}=\left(\bar{X}_{M}-\bar{X}_{W}\right) \tilde{\beta}_{M}+\bar{X}_{W}\left(\tilde{\beta}_{M}-\tilde{\beta}_{W}\right)+\left(\bar{e}_{M}-\bar{e}_{W}\right)$. The left-hand side of the equation represents the difference in labour force participation between men and women. The first term on the right-hand side represents the part of the difference in labour force participation that is attributable to differences in human capital, productivity, and household's decisions. This difference called the "explained gap" and is considered the non-discriminatory component of the gender gap. The second term is 
present the explained differential (due to endowments). In Panel III, we present the unexplained differential (due to the coefficients). In Panel IV, we present the sample selection component. Finally, in Panel V, we present the percent-wise contribution of bullying to the explained labour force participation gap, employment gap and wage gap.

The outcomes suggest that there are significant differences between the majority and minority groups that cannot be explained by the exogenous variables. For instance, as shown in Panel III, men have more opportunities to participate in the labour force, to be employed and to receive higher wages than women. For the rest of the groups, the decomposition outcomes are similarly interpreted. What is of importance is that the bullying index plays a statistically significant role in determining the various gaps between the majority and minority groups in some cases. To be specific, the outcomes suggest that the labour force gaps between heterosexual men and gay men and between healthy and health-impaired people can be explained by bullying incidents. We should note, however, that although the bullying effect is statistically significant at the $10 \%$ level, the percentage value is rather small in both cases. Similarly, statistically significant bullying effects concerning the employment rate gaps are found between heterosexual men and gay men and between healthy and health-impaired individuals at the $10 \%$ level, respectively. Finally, the wage gap between heterosexual men and gay men can also be explained at the $5 \%$ level by the statistically significant effect of

called the "unexplained gap" and is considered to be caused by unobserved elements such as societal discrimination. The third part is called the " sample selection's correction term" which also takes the residual wage distribution into account. 
bullying $^{7}$. These decomposition outcomes may be reasonable. Several studies suggest that severe bullying can hold long-term consequences for minority groups, especially for gay men (Dew et al., 2006; Daley et al., 2008; Minton et al. 2008).

\section{[Table 8]}

\section{Conclusion}

The purpose of the current study was to examine whether adults who claim to have faced bullying as school-age students now face lower labour force participation, lower employment rates and lower hourly wages based on the Retrospective Bullying Questionnaire (Rivers 2001; Schafer et al., 2004; Hamburger et al., 2011) for the 2008 Greek Behavioural Study data set. The estimations suggest that higher levels of victimisation are associated with lower labour force participation, employment rates, and hourly wages. These results are in line with studies that used student data (Varhama and Björkqvist, 2005; Waddell, 2006; Le et al., 2005; Brown and Taylor, 2008). Naturally, this finding does not state anything about causality. It is not possible to claim that victims of school bullying run a greater risk of becoming people with lower labour prospects. Many contributing factors for both the school bullying and subsequent employment status during adulthood may play a critical role. Indeed, in the current study, we found a variety of interesting labour patterns through several specifications, which highlight the heterogeneity of the bullying effect on individuals' characteristics and suggest new research topics. Men, homosexuals, immigrants, unmarried people,

\footnotetext{
${ }^{7}$ If, instead of the bullying index (B), we use the frequency of bullying variable (FB), the intensity of bullying variable (IB), or both, we estimate comparable patterns. Estimations are available on request.
} 
those having higher negative mental health symptoms, and those having lower human capital are more negatively affected by bullying in terms of labour force participation, employment probability and wages. Various decompositions suggested that labour force gaps, employment gaps and hourly wage gaps between minority and majority groups (especially for gay men and the disabled) can be explained by bullying incidents.

The current study advanced the literature in many ways. The retrospective bullying index used in the current study measured the combined and ordered effect of the duration and intensity of bullying, which generates seventeen outcomes that ultimately capture a large range of alternative options. In addition, we suggested that bullying might be understood as a productivity trait that provides a direct input into the production process, which might drive abilities or traits and influence adult employment outcomes. Indeed, as previously discussed, scholarly studies show that bullying is associated with lower educational achievements and negative mental well-being, which can influence labour market outcomes (Le et al., 2005; Waddell, 2006; Brown and Taylor, 2008; Allison, et al. 2009; Orth, 2009; Goodman et al., 2011). Similarly, this study showed that adults who have adverse mental health symptoms are more likely to have been bullied. There was also evidence of a negative correlation between bullying and human capital - that is, higher education degrees, P/C and English skills were observed for those who had lower bullying experiences as children. Considering bullying as a proxy for unmeasured productivity may serve as a framework for integrating the existing body of evidence and structuring future research efforts. We suggest that a potentially important transmission mechanism between bullying, human capital and traits, and labour market outcomes exists. Thus, bullying may be of interest to economists, as bullying is considered to be a barometer for adult quality of life. 
Contemporary economic analysis suggests that cognitive and non-cognitive skills are important factors that affect labour productivity through reasoning ability and productivity.

Additional factors, of course, might have driven this study's outcomes. As already discussed, this study also offered a framework to outline why bullying might affect employment outcomes through differences in preferences, discrimination in the labour market, or both. If work-related preferences are related to bullying, bullying may indirectly affect employment and wages through occupational processes. In addition, labour market discrimination against victimised people could also affect current outcomes. These two research questions could drive new studies if suitable data are available. Bear in mind, however, that unobserved factors might also have influenced the associations between bullying and employment outcomes. Thus, this study should be viewed as exploratory and might drive other studies to address the aforementioned points. Thus, the results of this study are simply an indication of the relationship between bullying and employment outcomes.

Because the detrimental effects of bullying may have lasting effects that affect individuals' employment strategies, social planners and educational authorities should address victimisation through initiates such as funding intervention programmes and setting up legal requirements against bullying (see, Baldry and Farrington, 2007; Vreeman and Carroll, 2007). Indeed, most studies suggest that reducing violence at schools should lead to more investment in human capital (Diagne, 2009). These initiatives should be viewed as one aspect of the increasing concern for the rights of people not to experience harassment, which is now being extended to children in school. In addition, the existence of suitable data on this multifaceted phenomenon is required 
for proper evaluations. Economists should take account of this variable and related variables when estimating productivity and efficiency. There is substantial research suggesting that evidence-based prevention programs can reduce bullying, increase student sense of school safety and increase attachment to school (Vreeman and Carroll, 2007). 


\section{References}

Aiken, L. S. and West, S. G. (1991). Multiple regression: Testing and interpreting Interactions. Newbury Park, London, Sage.

Albee, G. W. (1988). A Model for Classifying Prevention Programs. In Albee, G. W. Joffe, J. M. and Dusenbury, L. A. (Eds.). Prevention, Powerlessness, and Politics: Readings on Social Change (pp. 13-22). Newbury Park, CA: Sage.

Allison, S. Roeger, L. and Reinfeld-Kirkman, N. (2009). Does School Bullying Affect Adult Health? Population Survey of Health-Related Quality of Life and Past Victimization. Australian and New Zealand Journal of Psychiatry. 43:1163-1170.

Andreou, E. and Metallidou, P. (2004). The Relationship of Academic and Social Cognition to Behavior in Bullying Situations Among Greek Primary School Children. Educational Psychology, 24: 27-41.

Arrow, K. J. (1998). What Has Economics to Say about Racial Discrimination? Journal of Economic Perspectives, 12:91-100.

Baldry, A. C. and Farrington, D. P . (2007). Effectiveness of Programs to Prevent School Bullying. Victims and Offenders, 2: 183-204.

Baldwin, L. M. and Johnson, W. G. (2000). Labour Market Discrimination Against Men with Disabilities in the Year of the ADA. Southern Economic Journal, 66: 548566.

Becker, G. S. (1957). The Economics of Discrimination. Chicago: University of Chicago Press.

Becker, G. S. (1975). Human Capital, 2nd ed. Chicago: University of Chicago Press.

Becker, G. S. (1993). Nobel Lecture: The Economic Way of Looking at Behavior. Journal of Political Economy: 101: 385-409. 
Blinder, A. S. (1973). Wage Discrimination: Reduced Form and Structural Estimates. Journal of Human Resources, 8(4): 436-455.

Brambor, T. Clark, W. R. and Golder, M. (2006). Understanding Interaction Models: Improving Empirical Analyses. Political Analysis, 14: 63-82.

Braumoeller, B. (2004). Hypothesis Testing and Multiplicative Interaction Terms. International Organization, 58: 807-820.

Brewin, C. R. Andrews, B. and Gotlib, I. H. (1993). Psychopathology and Early Experience: A Reappraisal of Retrospective Reports. Psychological Bulletin, 113: 82-89.

Boots, A. L. and van Ours, J. C. (2008). Job Satisfaction and Family Happiness: The Part-Time Work Puzzle. Economic Journal, 88: 1359-1386.

Boyce, C. J. (2010). Undersatnding Fixed Effects in Human Well-Being. Journal of Economic Psychology, 31:1-16.

Brown, S. and Taylor, K. (2008). Bullying, Education and Labour Market Outcomes: Evidence from the National Child Development Survey. Economics of Education Review, 27: 387-401.

Chapell, M. S. Casey, D. De la Cruz, C. Ferrell, J. Forman, J. Lipkin, R. Newsham, M. Sterling, M. and Whittaker, S. (2004). Bullying in College by Students and Teachers. Adolescence, 39: 53-64.

Chapell, M. S. Hasselman, S. L. Kitchin, T. Lomon, S. MacIver, K. W. and Sarulla, P. (2006). Bullying in Elementary School, High School, and College. Adolescence, 41: 633-648. 
Craig, W. M. (1998). The Relationship Among Bullying, Victimization, Depression, Anxiety, and Aggression in Elementary School Children. Personality and Individual Differences, 24: 123-130.

Craig, W. Harel-Fish, Y. Fogel-Grinvald, H. Dostaler, S. Hetland, J. Simons-Morton, B. Molcho, M. Gaspar de Mato, M. Overpeck, M. Due, P. Pickett, W. HBSC Violence and Injuries Prevention Focus Group, and HBSC Bullying Writing Group. (2009). A Cross-National Profile of Bullying and Victimization Among Adolescents in 40 Countries. International Journal of Public Health, 54: 216224.

Daley, A. Solomon. S. Newman, P. A. and Mishna, F. (2008). Traversing the Margins: Intersectionalities in the Bullying of Lesbian, Gay, Bisexual and Transgender Youth. Journal of Gay and Lesbian Social Services, 19: 9-29.

Dawson, J. F. and Richter, A. W. (2006). Probing Three-Way Interactions in Moderated Multiple Regression: Development and Application of a Slope Difference Test. Journal of Applied Psychology, 91: 917-926.

Dempsey, A. G. and Storch, E. A. (2008). Relational Victimization: The Association Between Recalled Adolescent Social Experiences and Emotional Adjustment in Early Adulthood. Psychology in the Schools, 45: 310-322.

Dew, B. J. Meyers, J. Singh, A. A. Marshall, M. L. and Graybill, E. C. (2006). School and Community Service Providers' Perspectives on Gay, Lesbian and Questioning Bullying, Journal of LGBT Issues in Counseling, 1: 45-66.

Diagne, D. (2009). School Violence: Evidence from the Economics Literature and Related Disciplines. Revue Suisse Des Sciences De L'Education, 31: 135-150. 
Digman, J. M. (1990). Personality Structure: Emergence of the Five-Factor Model. Annual Review of Psychology, 41: 417-40.

Dolton, P. J. and Kidd, M. P. (1994). Occupational Access and Wage Discrimination. Oxford Bulletin of Economics and Statistics, 56: 457-474.

Dooley, D. Prause, J. and Ham-Rowbottom, K. A. (2000). Underemployment and Depression: Longitudinal Relationships. Journal of Health and Social Behavior, 41: 421-436.

Espelage, D. L. and Swearer, S. M. (2003). Research on School Bullying and Victimization: What we Have Learned and Where Do we Go From Here? School Psychology Review, 32: 365-383.

Farmer, E. M. Z. (1995). Extremity of Externalizing Behavior and Young Adult Outcomes. Journal of Child Psychology and Psychiatry, 36: 617-632.

Fergusson, D. M. and Horwood, L. J. (1998). Early Conduct Problems and Later Life Opportunities. Journal of Child Psychology and Psychiatry, 39: 1097-1108.

Ferrer-i-Carbonell, A. and Frijters, P. (2004). How Important is Methodology for the Estimates of the Determinants of Happiness? Economic Journal, 114: 641-659.

Fonzi, A. Genta, M. L. Menesini, E. Bacchini, D. Bonino, S. and Costabile, A. (1999). Italy, in P. K. Smith, Y. Morita, J. Junger-Tas, D. Olweus, R. Catalano and P. Slee (eds). The Nature of School Bullying: A Cross-National Perspective (140-56), London and New York: Routledge.

Giovazolias, T. Kourkoutas, E. Mitsopoulou, E. Georgiadi, M. (2010). The Relationship Between Perceived School Climate and the Prevalence of Bullying Behavior in Greek Schools: Implications for Preventive Inclusive Strategies. Procedia Social and Behavioral Sciences, 5: 2208-2215. 
Goodman, A. Joyce, R. and Smith, J. P. (2011). The Long Shadow Cast by Childhood Physical and Mental Problems on Adult Life. PNAS, 108: 6032-6037.

Greeg, P. and Machin, S. (2000). Child Development and Success or Failure in the Youth Labour Market. NBER Comparative Labor Market Series (pp. 247-288). Chicago: University of Chicago Press.

Grogger, J. (1997). Local Violence and Educational Attainment. Journal of Human Resources, 32: 659-682.

Hamburger, M. E. Basile, K. C. Vivolo, A. M. (2011). Measuring Bullying Victimization, Perpetration, and Bystander Experiences: A Compendium of Assessment Tools. Atlanta, GA: Centers for Disease Control and Prevention, National Center for Injury Prevention and Control.

Hawker, D. S. J. and Boulton, M. J. (2000). Twenty Years Research on Peer Victimization and Psychosocial Maladjustment: A Meta-Analytic Review of Cross-Sectional Studies. Journal of Child Psychology and Psychiatry, 41: 441455.

Heckman, J. J. (1979). Sample Selection Bias as a Specification Error. Econometrica, 47: 153-161.

Heineck, S. and Anger, G. (2010). The Returns to Cognitive Abilities and Personality Traits in Germany. Labour Economics, 17: 535-546.

Holt, M. K. Finkelhor, D. and Kantor, K. G. (2007). Multiple Victimization Experiences of Urban Elementary School Students: Associations with Psychosocial Functioning and Academic Performance. Child Abuse and Neglect, 31: 503-515. 
Hugh-Jones, S., and Smith, P. K. (1999). Self-Reports of Short-and Long-Term Effects of Bullying on Children who Stammer. British Journal of Educational Psychology, 69: 141-158.

Irwin, M. Artin, K. H. and Oxman, M. N. (1999). Screening for Depression in the Older Adult: Criterion Validity of the 10-item Center for Epidemiological Studies Depression Scale (CES-D). Archives of Internal Medicine, 159: 1701-1704.

Jantzer, A. M. Hoover, J. H. and Narloch, R. (2006). The Relationship Between School aged Bullying and Trust, Shyness, and Quality of Friendships in Young Adulthood: A Preliminary Research Note. School Psychology International, 27: 146-156.

Juvonen, J. Wang, Y. and Espinoza, G. (2011). Bullying Experiences and Compromised Academic Performance Across Middle School Grades. The Journal of Early Adolescence, 31: 152-173.

Kaltiala-Heino, R. Rimpela, M. Marttunen, M. Rimpela, A. and Rantanen, P. (1999). Bullying, Depression, and Suicidal Ideation in Finnish Adolescents: School Survey. British Medical Journal, 319: 348-351.

Klomek, A. B. Marrocco, F. Kleinman, M. Schonfeld, I. S. and Gould, M. S. (2007). Bullying, Depression, and Suicidality in Adolescents. American Academy of Child and Adolescent Psychiatry, 46: 40-49.

Le, T. A. Miller, W. P. Heath, C. A. and Martin, N. (2005). Early Childhood Behaviours, Schooling and Labour Market Outcomes: Estimates from a Sample of Twins. Economics of Education Review, 24: 1-17. 
Ledley, D. R. Storch, E. A. Coles, M. E. Heimburg, R. G. Moser, J. and Bravata, E.(2006). The Relationship Between Childhood Teasing and Later Interpersonal Functioning. Journal of Psychopathology and Behavioral Assessment, 28: 33-40.

Lemieux, T. (2006). The Mincer Equation Thirty Years After. Schooling, Experience and Earnings, in Grossbard, S. (Ed.), Jacob Mincer. A Pioneer of Modern Labor Economics, Part IV, pp. 127-145. Springer.

Likert, R. (1932). A Technique for the Measurement of Attitudes. Archives of Psychology, 140:1-55.

McCrae, R. R. and John, O. P. (1992). An Introduction to the Five-Factor Model and its Applications. Journal of Personality, 60: 175-215.

Mauk, G and Rodgers, P. (1994). Building Bridges Over Troubled Waters: SchoolBased Postvention With Adolescent Survivors of Peer-suicide. Crisis Intervention Time Limited Treatment, 1: 103-123.

Menesini, E. Codecasa, E. Benelli, B. and Cowie, H. (2003). Enhancing Children's Responsibility to Take Action Against Bullying: Evaluation of a Befriending Intervention in Italian Middle Schools. Aggressive Behavior, 29: 1-14.

Miller, S. R. (1998). Shortcut: High School Grades as a Signal of Human Capital. Educational Evaluation and Policy Analysis, 20:299-311.

Mincer, J. (1958). Investment in Human Capital and Personal Income Distribution. Journal of Political Economy, 66: 281-302.

Minton, S. J. Dahl, T. O’ Moore, A. M. And Tuck, D. (2008). An Exploratory Survey of the Experiences of Homophobic Bullying Among Lesbian, Gay, Bisexual and Transgendered Young People in Ireland. Irish Educational Studies, 27: 177-191. 
Mueller, G. and Plug, E. J. S. (2006). Estimating the Effect of Personality on Male and Female Earnings. Industrial and Labor Relations Review, 60: 3-22.

Meyers, J. and Meyers, B. (2003). Bidirectional Influences Between Positive Psychology and Primary Prevention. School Psychology Quarterly, 18: 222-229.

Nakamoto, J. and Schwartz, D. (2009). Is Peer Victimization Associated with Academic Achievement? A meta-analytic review. Social Development, 19: 221-242.

Nansel, T. R. Craig, W. Overpeck, M. D. Saluja, G. and Ruan, W. J. (2004). Crossnational Consistency in the Relationship Between Bullying Behaviors and Psychosocial Adjustment. Archives of Pediatrics and Adolescent Medicine, 158: 730-736.

Newman, M. L. Holden, G. W. and Delville, Y. (2005). Isolation and the Stress of Being Bullied. Journal of Adolescence, 45: 343-357.

Nishina, A. Juvonen, J. and Witkow, M. R. (2005). Sticks and Stones May Break My Bones, But Names Will Make Me Feel Sick: The Psychosocial, Somatic, and Scholastic Consequences of Peer Harassment. Journal or Clinical Child and Adolescent Psychology, 34: 37-48.

Oaxaca, R. (1973). Male-Female Wage Differentials in Urban Labour Markets. International Economic Review, 14(3): 693-709.

Olweus, D. (1993). Bullying in School: What We Know And What We Can Do. Oxford: Blackwell.

O’Moore, M. (2000). Critical Issues for Teacher Training to Counter Bullying and Victimization in Ireland. Aggressive Behavior, 26: 99-111. 
Orth, U. Robins, R. W. Trzesniewski, K. H. Maes, J. and Schmitt, M. (2009). Low Selfesteem is a Risk Factor for Depressive Symptoms Across the Life Span. Journal of Abnormal Psychology, 188: 472-478.

Pateraki, L. and Houndoumadi, A. (2001). Bullying Among Primary School Children in Athens, Greece. Educational Psychology, 21: 167-75.

Paunonen, S. V. and Ashton, M. C. (2001). Big Five Factors and Facets and the Prediction of Behavior. Journal of Personality and Social Psychology, 81: 524539.

Pellegrini, A. D. and Long, J. D. (2002). A Longitudinal Study of Bullying, Dominance, and Victimisation during the Transition from Primary School through Secondary School. British Journal of Developmental Psychology, 20: 259-80.

Pereira, B. Mendonça, D. Neto, C. Valente, L. and Smith, P. K. (2004). Bullying in Portuguese Schools. School Psychology International, 25: 241-54.

Radloff, L. S. (1977). The CES-D Scale: A Self-Report Depression Scale for Research in the General Population. Journal of Applied Psychological Measures, 1: 385401.

Rigby, K. (1997). Bullying in Schools: And What to Do About It. London: Jessica Kingsley.

Rigby, K. (2003). Consequences of Bullying in Schools. Canadian Journal of Psychiatry, 48: 583-590.

Rivers, I. (2001). Retrospective Reports of School Bullying: Recall Stability and its Implications for Research. British Journal of Developmental Psychology, 19: $129-142$. 
Roth, P. L. BeVier, C. A. Switzer, F. S. Schippmann, J. S. (1996). Meta-Analyzing the Relationship Between Grades and Job Performance. Journal of Applied Psychology, 81:548-556.

Roth, D. A. Coles, M. E. and Heimburg, R. G. (2002). The Relationship Between Memories for Childhood Teasing and Anxiety and Depression in Adulthood. Anxiety Disorders, 16: 149-164.

Sapouna, M. (2008). Bullying in Greek Primary and Secondary Schools. School Psychology International, 29: 199-213.

Savoca, E. and Rosenheck, R. (2000). The Civilian Labor Market Experiences of Vietnam-Era Veterans: the Influence of Psychiatric Disorders. Journal of Mental Health and Policy Economics, 3: 199-207.

Schafer, M. Korn, S. Smith, P. K. Hunter, S. C. Mora-Merchan, J. A. Singer, M. M. van der Meuler, K. (2004). Lonely in the Crowd: Recollection of Bullying. British Journal of Developmental Psychology, 22: 379-394.

Shenkman, G. and Shmotkin D. (2011) Mental Health Among Israeli Homosexual Adolescents and Young Adults. Journal of Homosexuality, 58: 97-116.

Schwartz, D. Dodge, K. A. Coie, J. D. (1993). The Emergence of Chronic Peer Victimization in Boys' Play Groups. Child Development, 64: 1755-1772.

Schwartz, D. Gorman, A. H. Nakamoto, J. and Toblin, R. L. (2005). Victimization In the Peer Group and Children's Academic Functioning. Journal of Educational Psychology, 97: 425-435.

Smith, P. K. (1991). The Silent Nightmare: Bullying and Victimization in School Peer Groups. The Psychologist, 4: 243-248. 
Smith, P. K. Morita, Y. Junger-Tas, J. Olweus, D. Catalano, R. and Slee, P. (1999). The Nature of School Bullying: A Cross-National Perspective, London and New York: Routledge.

Smith, P. K. and Brain, P. (2000). Bullying in Schools: Lessons from Two Decades of Research. Aggressive Behavior, 26: 1-9.

Smith, P. K. Singer, M. Hoel, H. and Cooper, C. (2003). Victimizations in the School and the Workplace: Are There Any Links? British Journal of Psychology, 94: $175-188$.

Smokowski, P. R. and Holland, K. (2005). Bullying in School: Correlates, Consequences, and Intervention Strategies for School Social Workers. Children and Schools, 27: 101-110.

Stanbury, J. P. Ried, L. D. and Velozo, C. A. (2006). Undimensionality and Bandwidth in the Center for Epidemiologic Studies Depression (CES-D) Scale. Journal of Personality Assessment, 86: 10-22.

Turban, D. B. and Cable, D. M. (2003). Firm Reputation and Applicant Pool Characteristics. Journal of Organizational Behavior, 24: 733-751.

Varhama, L. and Björkqvist, K. (2005). Relation Between School Bullying During Adolescence and Subsequent Long Term Unemployment in Adulthood in a Finnish Sample. Psychological Reports, 96:269-272.

Vreeman, R. C. and Carroll, A. E. (2007). A Systematic Review of School-Based Interventions to Prevent Bullying. Archives of Pediatric and Adolescent Medicine, 161: 78-88.

Waddell, G. (2006). Labor-Market Consequences of Poor Attitude and Low SelfEsteem in Youth. Economic Inquiry, 44:69-97. 
Whitney, I. and Smith, P. K. (1993). A Survey of the Nature and Extent of Bully/Victim Problems in Junior/Middle and Secondary Schools. Educational Research, 35: 325.

Woods, S. Done, J. and Kalsi, H. (2009). Peer Victimization and Internalizing Difficulties: The Moderating Role of Friendship Quality. Journal of Adolescence, 32: 293-308.

Wooldridge, J. M. (2006). Introductory Econometrics: a Modern Approach. Florence, Thomson, South-Western. 
Table 1. Proportion estimation of bullying

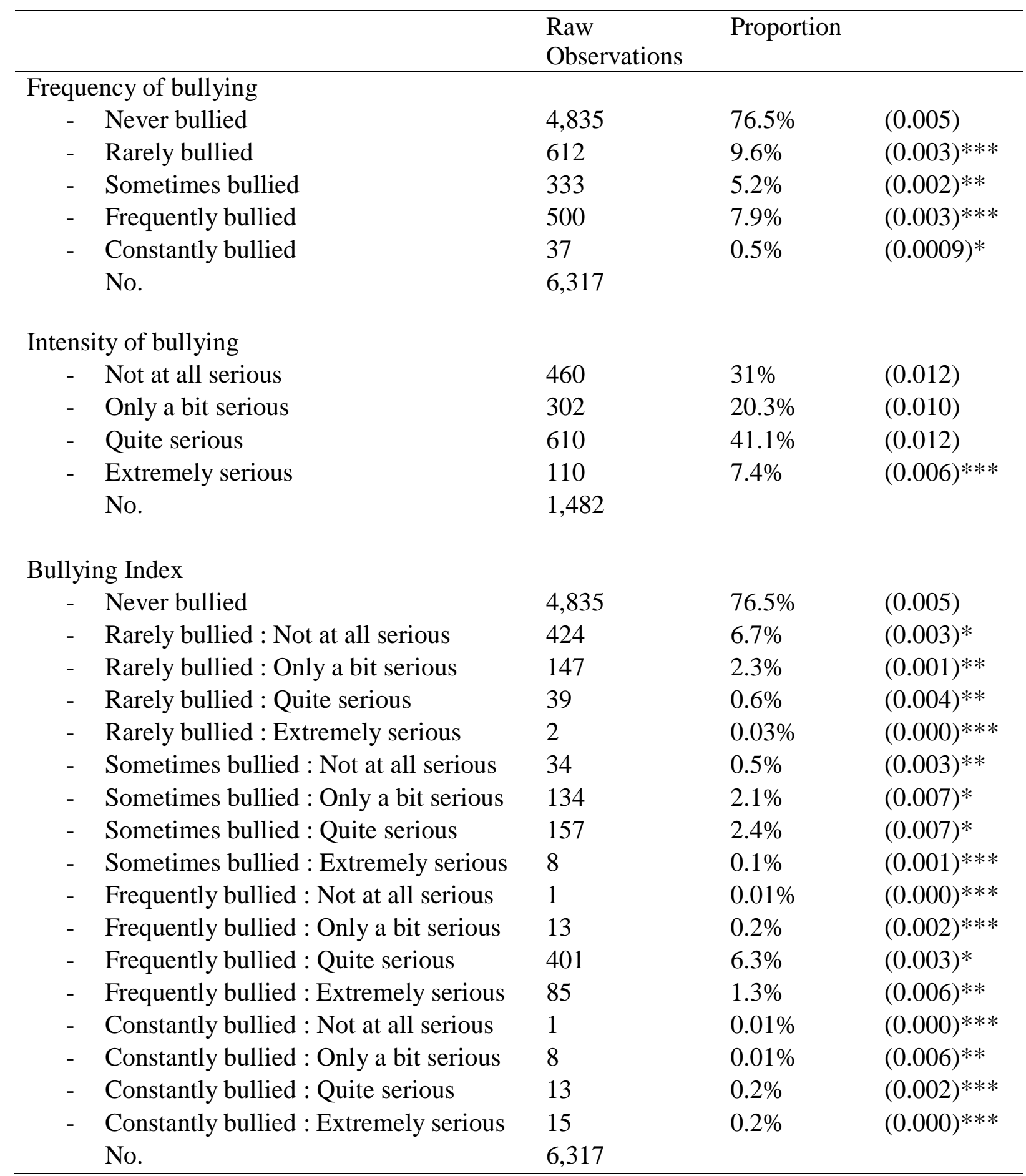

Notes: Data Sources Greek Behavioral Study 2008. Standard errors of the proportions are in parenthesis.

*Significant at the $10 \%$ level. **Significant at the $5 \%$ level. ***Significant at the $1 \%$ level. 
Table 2. Descriptive statistics: Mean and standard deviation

\begin{tabular}{|c|c|c|c|}
\hline & Mean & $\begin{array}{l}\text { Standard } \\
\text { Errors }\end{array}$ & $\begin{array}{l}\text { Standard } \\
\text { Deviation }\end{array}$ \\
\hline Frequency of bullying & 0.46 & $(0.01)$ & 0.94 \\
\hline Intensity of bullying & 0.55 & $(0.01)$ & 1.10 \\
\hline Bullying index & 1.25 & $(0.03)$ & 2.96 \\
\hline Age & 34.68 & $(0.14)$ & 11.59 \\
\hline Men & $47.44 \%$ & $(0.00)$ & 0.49 \\
\hline Homosexuals & $10.40 \%$ & $(0.00)^{*}$ & 0.30 \\
\hline Married & $58.38 \%$ & $(0.00)$ & 0.49 \\
\hline Number of individuals' children & 0.77 & $(0.01)$ & 0.92 \\
\hline Immigrants & $15.41 \%$ & $(0.00)$ & 0.36 \\
\hline Disability status & $7.77 \%$ & $(0.00)^{*}$ & 0.26 \\
\hline Adverse mental health symptoms & 1.50 & $(0.02)$ & 1.83 \\
\hline University or technical school degree & $47.99 \%$ & $(0.00)$ & 0.49 \\
\hline Computer skills & $58.69 \%$ & $(0.00)$ & 0.58 \\
\hline Knowledge of English & $49.75 \%$ & $(0.00)$ & 0.50 \\
\hline Participants (employed and unemployed) & $93.16 \%$ & $(0.00)$ & 0.25 \\
\hline Employed & $78.10 \%$ & $(0.00)$ & 0.41 \\
\hline Actual working experience & 12.54 & $(0.12)$ & 10.25 \\
\hline White collar jobs & $39.82 \%$ & $(0.00)$ & 0.48 \\
\hline Public jobs & $52.75 \%$ & $(0.00)$ & 0.49 \\
\hline Hourly wages $(€)$ & 7.90 & $(0.05)$ & 3.51 \\
\hline Extraversion & 4.20 & $(0.04)$ & 1.08 \\
\hline Agreeableness & 5.15 & $(0.04)$ & 1.05 \\
\hline Conscientiousness & 5.24 & $(0.04)$ & 1.00 \\
\hline Emotional stability & 5.09 & $(0.03)$ & 0.93 \\
\hline Openness & 4.21 & $(0.02)$ & 0.94 \\
\hline Non-labour income (monthly $€$ ) & 234.46 & $(0.35)$ & 28.46 \\
\hline $\begin{array}{l}\text { Mother's university or technical school } \\
\text { degree }\end{array}$ & $16.70 \%$ & $(0.04)$ & 0.25 \\
\hline $\begin{array}{l}\text { Father's university or technical school } \\
\text { degree }\end{array}$ & $20.58 \%$ & $(0.00)$ & 0.31 \\
\hline Observations & 6,317 & & \\
\hline
\end{tabular}

Notes: Data Sources Greek Behavioural Study 2008. Standard errors of the mean are in parenthesis. *Significant at the $10 \%$ level. 
Table 3. Bullying indicators' descriptive statistics: Employed, unemployed and non-participants

\begin{tabular}{|c|c|c|c|c|c|c|}
\hline & \multicolumn{2}{|c|}{ Employed } & \multicolumn{2}{|c|}{ Unemployed } & \multicolumn{2}{|c|}{ Non-participants } \\
\hline & Mean & $\begin{array}{l}\text { Standard } \\
\text { Deviation }\end{array}$ & Mean & $\begin{array}{l}\text { Standard } \\
\text { Deviation }\end{array}$ & Mean & $\begin{array}{l}\text { Standard } \\
\text { Deviation }\end{array}$ \\
\hline $\begin{array}{l}\text { Frequency of } \\
\text { bullying }\end{array}$ & $\begin{array}{l}0.39 \\
(0.01)^{* * * *}\end{array}$ & 0.90 & $\begin{array}{l}0.74 \\
(0.36)^{* * *}\end{array}$ & 1.12 & $\begin{array}{l}0.62 \\
(0.03) * * *\end{array}$ & 0.80 \\
\hline $\begin{array}{l}\text { Intensity of } \\
\text { bullying }\end{array}$ & $\begin{array}{l}0.45 \\
(0.01) * * *\end{array}$ & 1.03 & $\begin{array}{l}0.91 \\
(0.04) * * *\end{array}$ & 1.34 & $\begin{array}{l}0.84 \\
(0.05) * * *\end{array}$ & 1.05 \\
\hline Bullying index & $\begin{array}{l}1.08 \\
(0.04) * * *\end{array}$ & 2.82 & $\begin{array}{l}2.13 \\
(0.12)^{* * *}\end{array}$ & 3.71 & $\begin{array}{l}1.27 \\
(0.10)^{* * *}\end{array}$ & 2.17 \\
\hline Observations & 4,934 & & 951 & & 432 & \\
\hline
\end{tabular}

Notes: Data Sources Greek Behavioural Study 2008. Standard errors of the mean are in parenthesis. ***Significant at the $1 \%$ level. 
Table 4. Sub-correlation matrix $(28 \times 3)$

\begin{tabular}{|c|c|c|c|}
\hline & 1. Frequency of bullying & 2. Intensity of bullying & 3. Bullying Index \\
\hline 1. Frequency of bullying & 1.000 & - & - \\
\hline 2. Intensity of bullying & $0.954 * * *$ & 1.000 & - \\
\hline 3. Bullying Index & $0.962 * * *$ & 0.941 & 1.000 \\
\hline 4. Age & $-0.132 * * *$ & $-0.135 * * *$ & $-0.137 * * *$ \\
\hline 5. Men & $0.164 * * *$ & $0.140 * * *$ & $0.186 * * *$ \\
\hline 6. Homosexuals & $0.632 * * *$ & $0.609 * * *$ & $0.595 * * *$ \\
\hline 7. Married & $-0.330 * * *$ & $-0.330 * * *$ & $-0.301 * * *$ \\
\hline $\begin{array}{l}\text { 8. Number of individuals' } \\
\text { children }\end{array}$ & $-0.217 * * *$ & $-0.212 * * *$ & $-0.200 * * *$ \\
\hline 9. Immigrants & $0.030 * *$ & $0.019 *$ & $0.026 * *$ \\
\hline 10. Disability status & $0.153 * * *$ & $0.169 * * *$ & $0.131 * * *$ \\
\hline $\begin{array}{l}\text { 11. Adverse mental health } \\
\text { symptoms }\end{array}$ & $0.226 * * *$ & $0.261 * * *$ & $0.187 * * *$ \\
\hline $\begin{array}{l}\text { 12. University or technical } \\
\text { school degree }\end{array}$ & $-0.100 * * *$ & $-0.108 * * *$ & $-0.091 * * *$ \\
\hline 13. Computer skills & $-0.020^{*}$ & $-0.023 * * *$ & $-0.019 * * *$ \\
\hline 14. Knowledge of English & $-0.060 * * *$ & $-0.066 * * *$ & $0.055 * * *$ \\
\hline $\begin{array}{l}\text { 15. Participation in the labour } \\
\text { force }\end{array}$ & $-0.045^{* *}$ & $-0.072 * *$ & $-0.002 *$ \\
\hline 16. Employed & $-0.166 * * *$ & $-0.165 * * *$ & $-0.110 * * *$ \\
\hline 17. Actual working experience & $-0.134 * * *$ & $-0.146 * * *$ & $-0.120 * * *$ \\
\hline 18. White collar jobs & -0.006 & -0.004 & -0.009 \\
\hline 19. Public jobs & 0.002 & -0.004 & -0.001 \\
\hline 20. Hourly wages & $-0.197 * * *$ & $-0.205 * * *$ & $-0.178 * * *$ \\
\hline 21. Extraversion & $-0.649 * *$ & $-0.735 * *$ & $-0.722 * *$ \\
\hline 22. Agreeableness & -0.462 & -0.352 & -0.472 \\
\hline 23. Conscientiousness & 0.483 & 0.473 & 0.395 \\
\hline 24. Emotional stability & -0.395 & -0.377 & -0.306 \\
\hline 25. Openness & 0.382 & 0.472 & 0.399 \\
\hline $\begin{array}{l}\text { 26. Non-labour income } \\
\text { (monthly) }\end{array}$ & 0.283 & 0.371 & 0.320 \\
\hline $\begin{array}{l}\text { 27. Mother's university or } \\
\text { technical school degree }\end{array}$ & 0.382 & 0.364 & 0.377 \\
\hline $\begin{array}{l}\text { 28. Father's university or } \\
\text { technical school degree }\end{array}$ & 0.372 & 0.392 & 0.304 \\
\hline
\end{tabular}

Notes: Data Sources Greek Behavioural Study 2008. We use Spearman correlation coefficient to estimate correlations for both scales ordinal. We use Biserial correlation coefficient to estimate correlations between ordinal and quantitative variables. We use Rank-Biserial correlation coefficient to estimate correlations between ordinal and nominal variables. *Significant at the $10 \%$ level. **Significant at the 5\% level. ***Significant at the $1 \%$ level. 
Panel

Labour force participation

$-0.040(0.006) * * *$

$-0.003(0.010)$

$0.000(0.0001)^{* * * *}$

$0.032(0.004)^{* * *}$

$-0.017(0.002)^{* * *}$

$0.008(0.004)^{*}$

$-0.004(0.004)$

Number of

individuals' children

Immigrants

Disability status

Mental health

University or

technical school

degree

Actual working

experience

Computer skills

Knowledge of

English

White collar jobs

Public jobs

Extraversion

Agreeableness

Conscientiousness

Emotional stability

Openness

Non-labour income

(monthly)

Mother's university

or technical school

degree

Father's university or

technical school

degree

$\mathrm{V}$ coefficient

Pseudo R ${ }^{2}$

Prob $>\mathrm{chi}^{2}$

Adj. $\mathrm{R}^{2}$

Prob $>\mathrm{F}$

Observations

$-0.055(0.014) * * *$

$-0.352(0.013) * * *$

$-0.001(0.000) * *$

$0.051(0.005)^{* * *}$

$0.103(0.045)^{* * *}$

$0.049(0.034)$

$0.230(0.118)^{* *}$

$0.324(0.058) * * *$

$0.466(0.034) * * *$
Panel II Panel III

Employment rate

Hourly wages (ln)

$\begin{array}{ll}-0.031(0.007) * * * & -0.019(0.005)^{* * *} \\ -0.008(0.001)^{* * *} & 0.022(0.000)^{* * *} \\ 0.000(0.0001)^{* * *} & -0.000(0.0001)^{* * *} \\ 0.041(0.008)^{* * *} & 0.098(0.007)^{* * *} \\ -0.120(0.003)^{* * *} & -0.036(0.016)^{* *} \\ -0.000(0.013) & 0.181(0.010)^{* * *} \\ 0.009(0.006) & 0.004(0.005)\end{array}$

$-0.000(0.003)$

$-0.072(0.009) * * *$

$-0.066(0.022)^{* * *} \quad-0.089(0.015)^{* * *}$

$-0.011(0.002) * * *$

$0.054(0.008) * * *$

$-0.010(0.003) * * *_{-}$

$0.082(0.020)^{* * *}$

$\begin{array}{lll}0.006(0.000) * * * & 0.080(0.000)^{* * * *} & 0.064(0.000)^{* * * *} \\ -0.030(0.026) & 0.063(0.017) * * * & -0.035(0.042) \\ -0.003(0.003) & -0.008(0.007) & 0.009(0.010)\end{array}$

$0.051(0.010)^{* * *}$

$0.042(0.013) * * *$

$0.045(0.023) * *$

$0.063(0.055)$

$0.088(0.122)$

$0.112(0.177)$

$0.030(0.047)$

$0.074(0.035)$
$0.051(0.045)$

$0.095(0.075)$

$0.066(0.060)$

$0.041(0.053)$

-

$\begin{array}{ll}0.058(0.030)^{*} & 0.058(0.030)^{*} \\ 0.053 & - \\ 0.000 & - \\ - & 0.734 \\ - & 0.000 \\ 5.885 & 4,934\end{array}$

4,934

Notes: Data Sources Greek Behavioural Study 2008. In Panel I we use Probit model. In Panel II we use Bivariate Probit. In Panel III we use a Heckit model *Significant at the $10 \%$ level. **Significant at the 5\% level. ***Significant at the $1 \%$ level. 


\begin{tabular}{|c|c|c|c|}
\hline & $\begin{array}{l}\text { Panel I } \\
\text { Labour force } \\
\text { participation }\end{array}$ & $\begin{array}{l}\text { Panel II } \\
\text { Employment rate }\end{array}$ & $\begin{array}{l}\text { Panel III } \\
\text { Hourly wages (ln) }\end{array}$ \\
\hline Bullying index & $-0.039(0.006)^{* * *}$ & $-0.030(0.007)^{* * *}$ & $-0.019(0.005)^{* * * *}$ \\
\hline Never bullied & $0.050(0.024)^{* * *}$ & $0.019(0.008) * * *$ & $0.032(0.010) * * *$ \\
\hline Rarely bullied : Not at all serious & $-0.010(0.005)^{* * *}$ & $-0.003(0.002)^{* *}$ & $-0.006(0.004)^{*}$ \\
\hline Rarely bullied : Only a bit serious & $-0.010(0.004)^{* * *}$ & $-0.003(0.002)^{*}$ & $-0.006(0.004)^{*}$ \\
\hline Rarely bullied : Quite serious & $-0.013(0.006)^{* * *}$ & $-0.010(0.004)^{* * *}$ & $-0.008(0.004)^{*}$ \\
\hline Sometimes bullied : Only a bit serious & $-0.014(0.005)^{* * *}$ & $-0.014(0.005)^{* * *}$ & $-0.011(0.000)^{* * *}$ \\
\hline Sometimes bullied : Quite serious & $-0.021(0.000)^{* * *}$ & $-0.014(0.008)^{*}$ & $-0.013(0.005)^{* * *}$ \\
\hline Frequently bullied : Quite serious & $-0.025(0.000)^{* * *}$ & $0.020(0.003)^{* * *}$ & $-0.016(0.000)^{* * *}$ \\
\hline Frequently bullied : Extremely serious & $-0.037(0.000)^{* * *}$ & $0.027(0.000)^{* * *}$ & $-0.018(0.000)^{* * *}$ \\
\hline Constantly bullied : Extremely serious & $-0.059(0.000)^{* * *}$ & $-0.040(0.018)^{* * *}$ & $-0.039(0.000)^{* * *}$ \\
\hline Age & $-0.003(0.009)$ & $-0.008(0.001)^{* * *}$ & $0.025(0.000)^{* * *}$ \\
\hline $\mathrm{Age}^{2}$ & $0.000(0.0001)^{* * *}$ & $0.000(0.0001)^{* * *}$ & $-0.000(0.0001)^{* * *}$ \\
\hline Men & $0.032(0.005)^{* * *}$ & $0.040(0.014)^{* * *}$ & $0.084(0.005)^{* * *}$ \\
\hline Homosexuality & $-0.015(0.005)^{* * *}$ & $-0.113(0.011)^{* * *}$ & $-0.033(0.017)^{*}$ \\
\hline Married & $0.008(0.004)^{* * *}$ & $-0.000(0.009)$ & $0.114(0.027)^{* * *}$ \\
\hline Number of individuals' children & $-0.004(0.004)$ & $0.009(0.005)$ & $0.005(0.005)$ \\
\hline Immigrants & $-0.050(0.012)^{* * *}$ & $-0.000(0.003)$ & $-0.069(0.010) * * *$ \\
\hline Disability status & $-0.207(0.035)^{* * *}$ & $-0.062(0.012)^{* * *}$ & $-0.087(0.008) * * *$ \\
\hline Mental health & $-0.001(0.000)^{* *}$ & $-0.009(0.004) * * *$ & $-0.011(0.002)^{* * *}$ \\
\hline University or technical school degree & $0.061(0.010)^{* * *}$ & $0.054(0.010)^{* * *}$ & $0.082(0.023)^{* * *}$ \\
\hline Actual working experience & $0.008(0.000)^{* * *}$ & $0.120(0.000)^{* * *}$ & $0.102(0.000)^{* * *}$ \\
\hline Computer skills & $-0.020(0.021)$ & $0.036(0.015)^{* * *}$ & $-0.031(0.032)$ \\
\hline Knowledge of English & $-0.003(0.003)$ & $-0.007(0.007)$ & $0.011(0.006)$ \\
\hline White collar jobs & - & - & $0.048(0.009)^{* * *}$ \\
\hline Public jobs & - & - & $0.036(0.010)^{* * *}$ \\
\hline Extraversion & $0.103(0.045)^{* * *}$ & $0.074(0.035)^{* * *}$ & $0.044(0.023)^{* *}$ \\
\hline Agreeableness & $0.048(0.034)$ & $0.052(0.048)$ & $0.063(0.055)$ \\
\hline Conscientiousness & $0.110(0.103)$ & $0.095(0.074)$ & $0.088(0.125)$ \\
\hline Emotional stability & $0.211(0.199)$ & $0.066(0.058)$ & $0.112(0.177)$ \\
\hline Openness & $0.049(0.034)$ & $0.041(0.053)$ & $0.029(0.047)$ \\
\hline Non-labour income (monthly) & $0.230(0.118)^{* *}$ & - & - \\
\hline $\begin{array}{l}\text { Mother's university or technical school } \\
\text { degree }\end{array}$ & $0.324(0.058)^{* * *}$ & - & - \\
\hline $\begin{array}{l}\text { Father's university or technical school } \\
\text { degree }\end{array}$ & $0.466(0.027)^{* * *}$ & - & - \\
\hline $\mathrm{v}$ coefficient & & $0.058(0.030)^{*}$ & $0.058(0.030)^{*}$ \\
\hline Pseudo $\mathrm{R}^{2}$ & 0.045 & 0.056 & - \\
\hline Prob > chi ${ }^{2}$ & 0.000 & 0.000 & - \\
\hline Adj. $R^{2}$ & - & - & 0.744 \\
\hline Prob $>$ F & - & - & 0.000 \\
\hline Observations & 6,317 & 5,885 & 4,934 \\
\hline
\end{tabular}

Notes: Data Sources Greek Behavioural Study 2008. In Panel I we use Probit model. In Panel II we use Bivariate Probit. In Panel III we use a Heckit model *Significant at the 10\% level. **Significant at the $5 \%$ level. ***Significant at the $1 \%$ level. 


\begin{tabular}{|c|c|c|c|}
\hline & $\begin{array}{l}\text { Panel I } \\
\text { Labour force } \\
\text { participation }\end{array}$ & $\begin{array}{l}\text { Panel II } \\
\text { Employment rate }\end{array}$ & $\begin{array}{l}\text { Panel III } \\
\text { Hourly wages }(\ln )\end{array}$ \\
\hline Bullying index & $-0.039(0.006) * * *$ & $-0.030(0.007) * * *$ & $-0.019(0.008) * * *$ \\
\hline Age & $-0.003(0.010)$ & $-0.008(0.001)^{* * *}$ & $0.021(0.000) * * *$ \\
\hline $\begin{array}{l}\text { Age } \\
x \text { bullying index }\end{array}$ & $-0.002(0.003)$ & $-0.008(0.012)$ & $-0.013(0.018)$ \\
\hline $\mathrm{Age}^{2}$ & $0.000(0.0001)^{* * *}$ & $0.000(0.0001)^{* * *}$ & $-0.000(0.0001)^{* * *}$ \\
\hline Men & $0.032(0.004) * * *$ & $0.044(0.010)^{* * *}$ & $0.098(0.007)^{* * *}$ \\
\hline $\begin{array}{l}\text { Men } \\
\mathrm{x} \text { bullying index }\end{array}$ & $-0.018(0.000)^{* * *}$ & $-0.016(0.000) * * *$ & $-0.061(0.000) * * *$ \\
\hline Homosexuality & $-0.017(0.002)^{* * *}$ & $-0.120(0.003) * * *$ & $-0.035(0.016) * *$ \\
\hline $\begin{array}{l}\text { Homosexuality } \\
\mathrm{x} \text { bullying index }\end{array}$ & $-0.024(0.002)^{* * *}$ & $-0.019(0.002)^{* * *}$ & $-0.124(0.000) * * *$ \\
\hline Married & $0.008(0.004)^{* * *}$ & $-0.000(0.010)$ & $0.185(0.010)^{* * *}$ \\
\hline $\begin{array}{l}\text { Married } \\
\text { x bullying index }\end{array}$ & $0.020(0.000)^{* * *}$ & $0.016(0.00)^{* * *}$ & $0.078(0.000)^{* * *}$ \\
\hline Number of individuals' children & $-0.004(0.004)$ & $0.009(0.006)$ & $0.004(0.005)$ \\
\hline $\begin{array}{l}\text { Number of individuals' children } \\
\text { x bullying index }\end{array}$ & $-0.011(0.197)$ & $-0.015(0.064)$ & $-0.002(0.002)$ \\
\hline Immigrants & $-0.058(0.012) * * *$ & $-0.000(0.003)$ & $-0.073(0.009) * * *$ \\
\hline $\begin{array}{l}\text { Immigrants } \\
\mathrm{x} \text { bullying index }\end{array}$ & $-0.016(0.000)^{* * *}$ & $-0.019(0.000)^{* * * *}$ & $-0.041(0.000)^{* * *}$ \\
\hline Disability status & $-0.353(0.013) * * *$ & $-0.065(0.020)^{* * *}$ & $-0.086(0.014) * * *$ \\
\hline $\begin{array}{l}\text { Disability status } \\
\mathrm{x} \text { bullying index }\end{array}$ & $-0.015(0.010)$ & $0.006(0.007)$ & $-0.022(0.016)$ \\
\hline Mental health & $-0.001(0.000)^{* *}$ & $-0.011(0.002) * * *$ & $-0.010(0.003) * * *_{-}$ \\
\hline $\begin{array}{l}\text { Mental health } \\
\mathrm{x} \text { bullying index }\end{array}$ & $-0.018(0.000)^{* * *}$ & $-0.015(0.000)^{* * *}$ & $-0.050(0.000)^{* * *}$ \\
\hline $\begin{array}{l}\text { University or technical school } \\
\text { degree }\end{array}$ & $0.053(0.005)^{* * *}$ & $0.057(0.008)^{* * *}$ & $0.085(0.020)^{* * *}$ \\
\hline $\begin{array}{l}\text { University or technical school } \\
\text { degree } \\
\mathrm{x} \text { bullying index }\end{array}$ & $0.028(0.000) * * *$ & $0.018(0.000)^{* * *}$ & $0.039(0.000)^{* * *}$ \\
\hline Actual working experience & $0.006(0.000)^{* * *}$ & $0.080(0.000)^{* * *}$ & $0.063(0.000)^{* * *}$ \\
\hline $\begin{array}{l}\text { Actual working experience } \\
\mathrm{x} \text { bullying index }\end{array}$ & $0.031(0.000)^{* * *}$ & $0.155(0.000)^{* * *}$ & $0.089(0.000)^{* * *}$ \\
\hline Computer skills & $-0.030(0.020)$ & $0.067(0.017)^{* * *}$ & $-0.035(0.029)$ \\
\hline $\begin{array}{l}\text { Computer skills } \\
\mathrm{x} \text { bullying index }\end{array}$ & $0.027(0.020)$ & $-0.011(0.015)$ & $0.018(0.018)$ \\
\hline Knowledge of English & $-0.003(0.003)$ & $-0.008(0.007)$ & $0.010(0.005)$ \\
\hline $\begin{array}{l}\text { Knowledge of Engl } \\
\mathrm{x} \text { bullying index }\end{array}$ & $0.008(0.010)$ & $0.007(0.006)$ & $0.004(0.003)$ \\
\hline White collar jobs & - & - & $0.051(0.009)^{* * *}$ \\
\hline $\begin{array}{l}\text { White collar jobs } \\
\mathrm{x} \text { bullying index }\end{array}$ & - & - & $0.012(0.014)$ \\
\hline
\end{tabular}


Public jobs

Public jobs

$\mathrm{x}$ bullying index

Extraversion

Extraversion

$\mathrm{x}$ bullying index

Agreeableness

Agreeableness

$\mathrm{x}$ bullying index

Conscientiousness

Conscientiousness

$\mathrm{x}$ bullying index

Emotional stability

Emotional stability

$\mathrm{x}$ bullying index

Openness

Openness

$\mathrm{x}$ bullying index

Non-labour income (monthly)

Non-labour income (monthly)

$x$ bullying index

Mother's university or technical

school degree

Mother's university or technical

school degree

$\mathrm{x}$ bullying index

Father's university or technical

school degree

Father's university or technical

$0.103(0.043) * * *$

$0.037(0.028)$

$0.074(0.035)^{* * *}$

$0.162(0.160)$

$0.045(0.023)^{* *}$

$0.048(0.034)$

$0.051(0.045)$

$0.214(0.200)$

$0.042(0.012) * * *$

$0.033(0.030)$

$0.095(0.075)$

$0.032(0.031)$

$0.112(0.100)$

$0.188(0.154)$

$0.048(0.052)$

$0.044(0.040)$

$0.067(0.053)$

$0.041(0.040)$

$0.209(0.190)$

$0.068(0.060)$

$0.113(0.098)$

$0.088(0.122)$

$0.055(0.046)$

0.043 (0.040)

$0.110(0.177)$

$0.056(0.043)$

$0.049(0.037)$

$0.040(0.053)$

$0.030(0.048)$

$0.055(0.051)$

$0.122(0.101)$

0.039 (0.030)

$0.230(0.118)^{* *}$

$0.534(0.443)$

$0.324(0.058) * * *$

$0.038(0.105)$

$0.466(0.027)^{* * *}$

$0.028(0.099)$

school degree

$\mathrm{x}$ bullying index

$v$ coefficient

Pseudo $\mathrm{R}^{2}$

Prob $>\mathrm{chi}^{2}$

0.094

$0.058(0.030)^{*}$

$0.058(0.030)^{*}$

Adj. $R^{2}$

0.000

0.057

0.000

Prob > F

(6,

-

0.747

$\begin{array}{ll}- & 0.000\end{array}$

Observations

6,317

5,885

4,934

Notes: Data Sources Greek Behavioural Study 2008. In Panel I we use Probit model. In Panel II we use Bivariate Probit. In Panel III we use a Heckit model *Significant at the 10\% level. **Significant at the 5\% level. ***Significant at the $1 \%$ level. 
Table 8. Oaxaca-Blinder decomposition outcomes per group

\begin{tabular}{llllll}
\multirow{3}{*}{ Groups } & Panel I & Panel II & Panel III & Panel IV & Panel V \\
& Raw & Explained & Unexplained & Sample & Explained \\
& Differential & Differential & Differential & selection's & Differential due \\
& & (Due to & (Due to & correction & to \\
& endowments) & coefficients) & term & $\begin{array}{l}\text { bullying } \\
\text { (bullying index) }\end{array}$
\end{tabular}

\section{Labour force participation}

Men-Women

Natives-Immigrants

Heterosexual men

-Gay men

Heterosexual women

- Lesbian women

Healthy people-

The disabled

$0.106(0.000) * * *$
$-0.152(0.000) * * *$
$-0.022(0.008)$
$-0.031(0.016) * *$
$-0.451(0.000) * * *$

$0.968(0.000) * * *$

$0.949(0.000) * * *$

$0.986(0.000) * * *$

$0.984(0.000)^{* * *}$

$0.642(0.000) * * *$
$0.001(0.001) \quad 0.003(0.017)$

$0.002(0.003) \quad 0.005(0.005)$

$0.001(0.002) \quad 0.004(0.003)^{*}$

$0.013(0.000) * * *$

$0.002(0.005)$

$0.011(0.022)$

$0.014(0.000)^{* * *}$

$0.357(0.000) * * *$

$0.001(0.001)$

$0.098(0.050)^{*}$
Employment rate

\section{Men-Women}

Natives-Immigrants

Heterosexual men

-Gay men

Heterosexual women

- Lesbian women

Healthy people-

The disabled

$$
\begin{array}{ll}
0.144(0.000) * * * & 0.948(0.000) * * * \\
-0.064(0.034) * & 0.992(0.000) * * * \\
-0.196(0.000) * * * & 0.883(0.000) * * * \\
-0.239(0.000) * * * & 0.817(0.000) * * * \\
-0.133(0.018) * * * & 0.938(0.000) * * *
\end{array}
$$

$0.051(0.010) * * *$

$0.006(0.005)$

$0.115(0.003) * * *$

$0.180(0.000) * * *$

$0.059(0.014) * * *$

$0.001(0.001)$

$0.002(0.007)$

$0.002(0.010)$

$0.003(0.004)$

$0.002(0.002)$

$0.030(0.016) *$

$0.003(0.003) \quad 0.017(0.011)$

$0.003(0.004)$

$0.013(0.007)^{*}$

Hourly wages (ln)

Men - Women

Natives-Immigrants

Heterosexual men

-Gay men

Heterosexual women

- Lesbian women

Healthy people-

The disabled

$$
\begin{aligned}
& 0.167(0.011)^{* * * *} \\
& -0.211(0.000)^{* * *} \\
& -0.102(0.015)^{* * *} \\
& -0.112(0.021)^{* * *} \\
& -0.144(0.000)^{* * *}
\end{aligned}
$$

$0.090(0.005) * * *$

$0.071(0.000) * * *$

$0.037(0.010) * * *$

$0.026(0.010) * * *$

$0.971(0.000) * * *$

$0.911(0.000) * * *$

$0.081(0.000) * * *$
$0.002(0.002) \quad 0.006(0.009)$

$0.002(0.002) \quad 0.002(0.023)$

$0.004(0.005) \quad 0.010(0.006)^{* *}$

$0.003(0.002) \quad 0.017(0.010)$

$0.001(0.003) \quad 0.015(0.028)$

Notes: Data Sources Greek Behavioural Study 2008. We use the Oaxaca-Blinder Decomposition technique to compute the Estimations. Each line is a separate outcome. The exogenous variables used are the same as in Table 6. *Significant at the $10 \%$ level. **Significant at the $5 \%$ level. ***Significant at the $1 \%$ level. 


\section{Appendix.}

Definitions of variables

Variable Name
Labour force
Employed people
Unemployed people
Hourly wages
Frequency of bullying

Intensity of bullying

Bullying index

Age
Gender
Homosexuality
Marital status
Children
Immigrants
Disability

Mental health symptoms

\section{Extraversion}

Agreeableness

Conscientiousness

Emotional stability

Openness

University studies

Experience

Computer skills

English

White collar job

Public sector

Non-labour income

\section{Definition}

The number of participants in the labour force

The number of employed individuals

The number of unemployed individuals

Natural logarithm of hourly wages

Frequency of bullying:

0: Never bullied; 1: Rarely bullied; 2: Sometimes Bullied; 3: Frequently bullied; 4: Constantly bullied

Intensity of bullying:

1.1: not at all serious; 2.1: only a bit serious; 3.1 : quite serious ; 4.1: extremely serious

Bullying Index: Frequency of bullying category $\mathrm{x}$ Intensity of bullying category

Years of age

1 if individual is male; 0 otherwise

1 if individual is gay man or lesbian; 0 otherwise

1 if individual is married; 0 otherwise

Number of respondent's children

1 if individual is an immigrant; 0 otherwise

1 if individual is limited in kind or amount of work, has a mobility limitation, or has a personal care limitation; 0 otherwise

If individual has negative mental health symptom (CES-D 20 items) for last week (e.g., depressed, everything an effort, restless sleep, not happy, lonely, sad, could not get doing, and did not enjoy life)

1 if individual is characterized by extraversion (Big Five Personality Traits index); 0 otherwise

1 if individual is characterized by agreeableness (Big Five Personality Traits index); 0 otherwise

1 if individual is characterized by conscientiousness (Big Five Personality Traits index); 0 otherwise

1 if individual is characterized by emotional stability (Big Five Personality Traits index); 0 otherwise

1 if individual is characterized by openness (Big Five Personality Traits index); 0 otherwise

1 if individual has university or a technical school diploma; 0 otherwise

Years of actual working experience

1 if respondent has computer skills; 0 otherwise

1 if respondent has knowledge of English; 0 otherwise

1 if individual's occupation is among managerial or professional specialties, or the individual works in a technical, sales, or administrative support position; 0 otherwise

1 if individual is employed in the public sector; 0 if individual is employed in the private sector (PRIV; reference group)

Natural logarithm of non-labour income (monthly) 
Mother's university or technical school degree Father's university or technical school degree
1 if individual's mother has university or a technical school diploma; 0 otherwise

1 if individual's father has university or a technical school diploma; 0 otherwise 